\title{
Acid and Chemical Induced Conformational Changes of Ervatamin B. Presence of Partially Structured Multiple Intermediates
}

\author{
Monica Sundd ${ }^{1}$, Suman Kundu ${ }^{2}$ and Medicherla V. Jagannadham* \\ Molecular Biology Unit, Institute of Medical Sciences, Banaras Hindu University, Varanasi-221005, India
}

Received 11 June 2001, Accepted 21 September 2001

\begin{abstract}
The structural and functional aspects of ervatamin $B$ were studied in solution. Ervatamin B belongs to the $\alpha+\beta$ class of proteins. The intrinsic fluorescence emission maximum of the enzyme was at $350 \mathrm{~nm}$ under neutral conditions, and at $355 \mathrm{~nm}$ under denaturing conditions. Between $\mathrm{pH}$ 1.02.5 the enzyme exists in a partially unfolded state with minimum or no tertiary structure, and no proteolytic activity. At still lower $\mathrm{pH}$, the enzyme regains substantial secondary structure, which is predominantly a $\beta$-sheet conformation and shows a strong binding to 8-anilino-1napthalene-sulfonic acid (ANS). In the presence of salt, the enzyme attains a similar state directly from the native state. Under neutral conditions, the enzyme was stable in urea, while the guanidine hydrochloride $(\mathrm{GuHCl})$ induced equilibrium unfolding was cooperative. The GuHCl induced unfolding transition curves at $\mathrm{pH} 3.0$ and 4.0 were non-coincidental, indicating the presence of intermediates in the unfolding pathway. This was substantiated by strong ANS binding that was observed at low concentrations of GuHCl at both $\mathrm{pH} 3.0$ and 4.0. The urea induced transition curves at $\mathrm{pH}$ 3.0 were, however, coincidental, but non-cooperative. This indicates that the different structural units of the enzyme unfold in steps through intermediates. This observation is further supported by two emission maxima in ANS binding assay during urea denaturation. Hence, denaturant induced equilibrium unfolding pathway of ervatamin $B$, which differs from the acid induced unfolding pathway, is not a simple two-state transition but involves intermediates which probably accumulate at different stages of protein folding and hence
\end{abstract}

*To whom correspondence should be addressed.

Tel: 91-542-367936; Fax: 91-542-367568

E-mail: jvm@banaras.ernet.in

Present Address

${ }^{1}$ Department of Biochemistry, University of Iowa, Iowa City, IA 52242, USA

${ }^{2}$ Department of Biochemistry, Biophysics and Molecular Biology, Iowa State University, Ames, IA 50011, USA adds a new dimension to the unfolding pathway of plant proteases of the papain superfamily.

Keywords: Plant cysteine proteases, Ervatamin B, Protein folding, Cooperative transitions, Intermediate

\section{Introduction}

An interplay of various physicochemical forces-like hydrophobic interactions, ionic interactions, disulfide bonds, and other local as well as non-local interactions - maintain the three-dimensional structure of proteins. The conformational stability of the native protein is a function of external variables, such as temperature, $\mathrm{pH}$, ionic strength, and solvent composition. A quantitative analysis of the role of these variables in the structure formation is a requisite for the description of the forces that are responsible for the conformational stability, which in turn can provide insight into the molecular structure of the enzyme. A simple method for such studies involves the monitoring of conformational changes that are caused upon perturbation of a protein molecule by various agents, such as acid, $\mathrm{GuHCl}$, or urea.

With this view, conformational studies in solution have been initiated with ervatamin B, a novel plant cysteine protease that was isolated in our laboratory from the latex of a medicinal plant Ervatamia coronaria (Kundu et al., 2000). Ervatamin B seems to be a potential endopeptidase with many interesting features and probable applications. Ervatamin B (approximate $M_{r}$ 26, 000) has been biochemically characterized, and the preliminary X-ray analysis has been reported (Chakrabarti et al., 1999). Ervatamin B probably shares an ancestral gene with papain (21 N-terminal amino acid residues showed a 57\% sequence identity to papain). In many ways ervatamin B is distinct from papain, ervatamin $C$, and other cysteine proteases in terms of half cysteines (five) content, stability, etc., therefore, it is worth studying. The present investigation describes the biophysical characterization of ervatamin B in an endeavor to understand the structure-function relationship, the basis, and rationale of its physicochemical properties, as well as its 
folding-unfolding mechanism.

The folding mechanism of many small globular proteins is described in terms of the two-state model (Privalov, 1979), where either native or denatured states are highly populated. However, it has been shown that such phenomenon occurs through some kinetic intermediates that accumulated during the folding process (Ptitsyn, 1995; Gast et al., 1998). Protein folding involves a discrete pathway with the formation of intermediate states between the native and denatured states (Kim and Baldwin, 1990). It is also argued that the equilibrium molten globule state, which is observable under artificial conditions, such as low $\mathrm{pH}$ and low denaturant concentrations, may also be involved in physiological processes in the living cell (Bychkova et al., 1996). Therefore, the identification and characterization of the intermediate states that are populated during the folding process has received considerable attention, and a lot of effort is being made in this direction. These efforts yielded common characteristics to the intermediate states, especially that compact collapsed states with significant secondary structure appear in the folding process for a number of proteins (Khorasanizadeh et al., 1993; Kuwajima et al., 1993). The species (observed at equilibrium for a large number of proteins under mild denaturing conditions with properties of partially-folded states) made possible the study in real-time scale experiments. Such intermediates from different proteins of different structure types have some common characteristics, and are termed as "molten globule" to emphasize the possible occurrence of such an intermediate as a general physical state of globular proteins (Ptitsyn et al., 1990; Harding et al., 1991; Arai and Kuwajima, 1996).

There is not much information available about the molten globule state in multidomain proteins and its role in protein folding. It has been proposed that domains in the native molecules are independent folding units that assemble and produce native molecules (Garel, 1992). These structural regions are expected to fold independently, whether they are isolated or together. However, further studies in this respect are necessary. Studies on the different conformational states in the unfolding-refolding of multidomain proteins are important for an understanding of the principles that govern protein folding (Dobson, 1992).

The paradigm enzyme papain and other plant cysteine proteases that belong to the papain superfamily usually consist of two well-defined domains; therefore, they provide an excellent system for studies in understanding the foldingunfolding behavior of proteins in general and multidomain proteins in particular. Very little information is available about the general folding aspects of plant cysteine proteases of the papain family. All investigations so far have mainly involved papain (Hernandez-Arana and Soriano-Garcia, 1988; Xiao et al., 1993). Detailed studies regarding the intermediates and their role in the folding of papain have been recently initiated in our laboratory (Edwin and Jagannadham, 1998). Another novel cysteine protease ervatamin $\mathrm{C}$, with remarkable stability, was also isolated in our laboratory (Sundd et al., 1998). It has also been used as a model system to elucidate the folding behavior of plant cysteine proteases in particular (Kundu et al., 1999). Thus, studies about the individual variations within a family would certainly help to generalize the folding behavior of enzymes of the papain superfamily, and would complement their proposed mechanisms.

\section{Materials and Methods}

Materials Fresh latex, obtained from young stems of the plant Ervatamia coronaria, was used to purify the enzyme ervatamin B, as described previously (Kundu et al., 2000). Sodium tetrathionate was used throughout the purification procedure to avoid any complications due to autodigestion, and this inactive enzyme was used for all of the biophysical studies reported here. All of the physical properties of the enzyme are the same in both the active and inactive forms. Concentration of the enzyme was determined by spectrophotometry using an extinction coefficient $\varepsilon_{\mathrm{lcm}}^{1 \%}=20.5$ at $280 \mathrm{~nm}$ (Kundu et al., 2000) and also by Bradford assay. All other materials were as described previously (Kundu et al., 1999).

Absorbance spectroscopy Absorbance measurements were carried out on a Beckman DU-640B spectrophotometer that was equipped with a constant temperature cell holder. Protein concentration for all absorbance measurements was between 6 and $10 \mu \mathrm{M}$. Absorbance spectra were recorded between 260 and $320 \mathrm{~nm}$.

Fluorescence spectroscopy Fluorescence measurements were carried out on a Perkin-Elmer LS-5B spectrofluorometer that was equipped with a constant temperature cell holder. Protein concentration was between $0.015-0.025 \mathrm{mg} / \mathrm{ml}$. For tryptophan fluorescence of ervatamin B, the excitation was at $292 \mathrm{~nm}$ and emission was recorded from 300 to $400 \mathrm{~nm}$ with 10 and $5 \mathrm{~nm}$ slit widths for excitation and emission, respectively. For ANS fluorescence, the excitation was at $380 \mathrm{~nm}$. The emission spectra were collected between 400 and $600 \mathrm{~nm}$ with the same slit widths for excitation and emission as above.

Spectropolarimetric studies CD measurements were done on a JASCO J-500A spectropolarimeter that was equipped with a $500 \mathrm{~N}$ data processor. Conformational changes in the secondary structure were monitored in the region between 200 and $260 \mathrm{~nm}$ with a protein concentration of $0.1 \mathrm{mg} / \mathrm{ml}$ in a cuvette of $1 \mathrm{~mm}$ pathlength. Changes in the tertiary structure were observed in a $10 \mathrm{~mm}$ path length cuvette in the region between 260 and $320 \mathrm{~nm}$ at a protein concentration of $0.7 \mathrm{mg} / \mathrm{ml}$. After subtracting appropriate blanks, mean residue ellipticities were calculated, using the formula (Balasubramanian and Kumar, 1976) $[\theta]=\theta_{\text {obs }} \times \mathrm{MRW} / 10 \mathrm{cl}$, where $\theta_{\text {obs }}$ is the observed ellipticity in degrees, MRW is the mean residue weight, $\mathrm{c}$ is the concentration of protein in $\mathrm{g} / \mathrm{ml}$, and $\mathrm{l}$ is the path length in $\mathrm{cm}$. A mean residue molecular weight 110 was used. A sensitivity of $1 \mathrm{~m} \% \mathrm{~cm}$ was used for far-UV measurements, and $2 \mathrm{~m} / \mathrm{cm}$ was used for near-UV measurements. 
Acid denaturation of ervatamin $B$ in presence and absence of salt Acid denaturation of ervatamin $B$ was carried out as a function of $\mathrm{pH}$ using the following: $\mathrm{KCl}-\mathrm{HCl}(\mathrm{pH} 0.5-1.5)$, Gly$\mathrm{HCl}(\mathrm{pH} 2.0-3.5)$, sodium acetate $(\mathrm{pH} 4.0-5.5)$, sodium phosphate (pH 6.0-8.0), Tris- $\mathrm{HCl}(\mathrm{pH} 8.5-10.5)$, and Gly-NaOH $(\mathrm{pH} 11.0-$ 12.5). Concentrations of all of the buffers were $50 \mathrm{mM}$. A stock solution of the protein was added to the appropriate buffer, and incubated for $24 \mathrm{~h}$ at $25^{\circ} \mathrm{C}$. The final $\mathrm{pH}$ and concentration of the samples were measured again. Acid denaturation was also performed at various $\mathrm{pH}$ in the presence of increasing concentrations of $\mathrm{KCl}$.

Guanidine hydrochloride and urea induced unfolding Chemically induced denaturation of the enzyme at a given $\mathrm{pH}$ was performed at different concentrations of denaturants. Protein samples were incubated at the desired denaturant concentration for approximately $24 \mathrm{~h}$ at $25^{\circ} \mathrm{C}$ to attain equilibrium. The final concentration of the protein and denaturant were measured by spectrophotometry and refractive index, respectively. All of the unfolding transitions are analyzed as described (Shirley, 1995) in order to obtain transition midpoints, as well as to judge the cooperativity or non-cooperativity of the transitions. To obtain the transition midpoints from an equilibrium solvent denaturation curve, the regions of the curve preceding and following the transitions were fit to a straight line. For a comparison of the results that were obtained by various measures (molar ellipticity, fluorescence intensity, emission maximum, and relative activity), they were normalized and expressed as a fraction of the native protein that was unfolded (fraction unfolded). There $f_{u}$ was calculated as $f_{u}=\left(X_{n}-X_{o b s}\right) /\left(X_{n}-X_{u}\right)$, where $X_{n}$ is the signal for the native protein, $X_{u}$ is the respective signal of the denatured protein, and $\mathrm{X}_{\mathrm{obs}}$ is the observed signal under given conditions. $\mathrm{X}_{\mathrm{n}}$ and $X_{u}$ were obtained by extrapolation of the linear dependency of the signal on the concentration of the denaturant in the regions before and after transition, respectively. All of the spectroscopic measurements (at different concentrations of the denaturant) were performed against appropriate blanks that contained the denaturant in the absence of the enzyme.
Assay for enzyme activity The hydrolyzing activity of the enzyme (under various conditions of $\mathrm{pH}$ and in the presence of chemical denaturant) was monitored using the denatured natural substrate azoalbumin, following the described procedure (Kundu $e t$ $a l ., 2000)$. A control assay was performed with no enzyme in the reaction mixture and used as a reference. To monitor the effects of $\mathrm{pH}$ on the enzyme activity, the enzyme was equilibrated in a buffer of the prescribed $\mathrm{pH}$ for $24 \mathrm{~h}$. The aliquots were assayed separately, both at the same $\mathrm{pH}$ and at neutral $\mathrm{pH}$. The enzyme assays could not be done below $\mathrm{pH} 4.0$ since azoalbumin is insoluble. Therefore, the enzyme activity was checked below pH 4.0 using denatured hemoglobin as a substrate. In the case of denaturants, the enzyme was incubated overnight at the prescribed concentrations of the denaturant solution. The remaining activity was measured as previously described. The activity of the enzyme in the absence of denaturant was used as a reference.

ANS Binding Assay Exposure of hydrophobic surfaces in the enzyme was measured by its ability to bind to the fluorescent dye ANS (Semisotnov et al., 1991). A stock solution of ANS was prepared in methanol. The concentration of ANS was determined using an extinction coefficient of $\varepsilon=5000 \mathrm{M}^{-1} \mathrm{~cm}^{-1}$ at $350 \mathrm{~nm}$ (Khurana and Udgaonkar, 1994). The protein was incubated with a 100-fold molar excess of ANS for more than 30 min in darkness at room temperature, and ANS fluorescence was measured. The protein concentration was $0.015-0.05 \mathrm{mg} / \mathrm{ml}$.

\section{Results}

CD spectra The CD spectra of native and denatured ervatamin B at pH 7.0 are shown in Fig. 1.

In the aromatic region, the $\mathrm{CD}$ spectrum of native ervatamin B exhibits a positive peak that is centered at $278 \mathrm{~nm}$ (Fig. 1A), and a negative band that is centered at $295 \mathrm{~nm}$. At the latter wavelength, tyrosine and phenylalanine residues do not contribute to the CD spectra of proteins (Strickland et al., 1969; Strickland, 1974), and the negative band probably

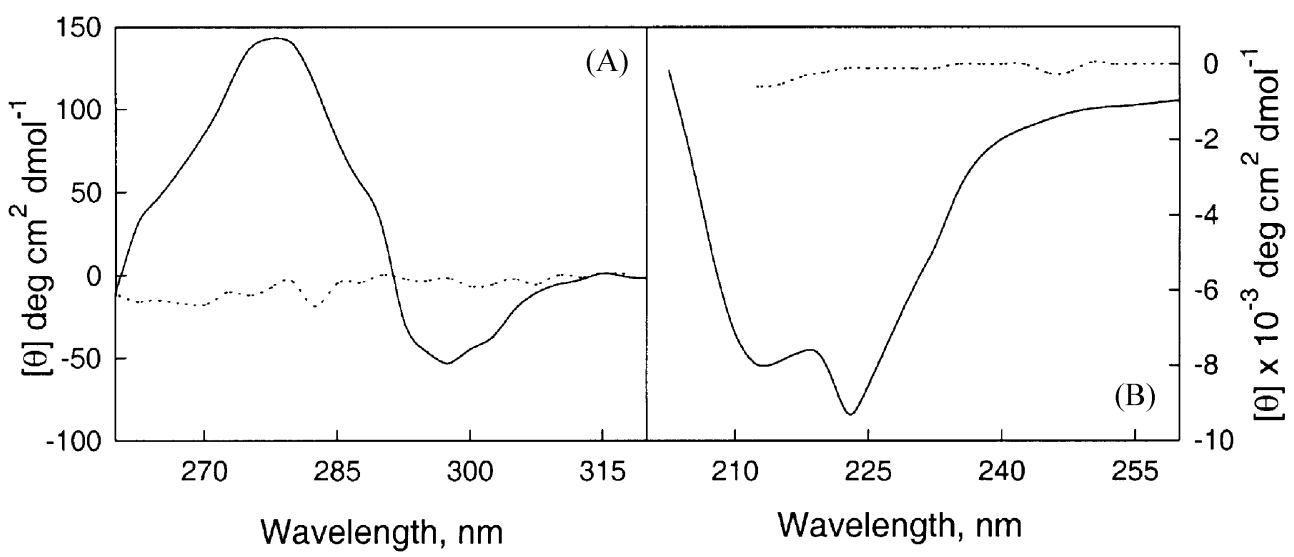

Fig. 1. CD spectra of native and denatured ervatamin B. (A) Near and (B) far-UV CD spectra of ervatamin $\mathrm{B}$ at (-) pH 7.0 and (---) $6 \mathrm{M} \mathrm{GuHCl}$. The samples were incubated for $24 \mathrm{~h}$ at $25^{\circ} \mathrm{C}$ before the measurements. Protein concentration was $0.1 \mathrm{mg} / \mathrm{ml}$ for far-UV $\mathrm{CD}$ and $0.7 \mathrm{mg} / \mathrm{ml}$ for near-UV CD. 
originates from tryptophan residues that are located in an asymmetrical environment (Solis-Mendiola, 1992). The intensity of the negative band at $297 \mathrm{~nm}$ is also much lower than the positive peak at $276-278 \mathrm{~nm}$.

In the far-UV region, native ervatamin B revealed two wellresolved negative peaks at $222 \mathrm{~nm}$ and $208 \mathrm{~nm}$ (Fig. 1B). The signal at $222 \mathrm{~nm}$ was greater in magnitude, which indicates the enzymes high level of structural integrity. The shape of the spectra, and strong negative ellipticities at 208, 215 and 222 $\mathrm{nm}$, suggest that ervatamin B is composed of $\alpha$-helix and $\beta$ sheet rich regions. It also appears to belong to the $\alpha+\beta$ class of proteins (Manavalan and Johnson, 1983). The mean residue ellipticity at $222 \mathrm{~nm}$ was $-9.1 \pm 0.5 \times 10^{3} \mathrm{deg} . \mathrm{cm}^{2} \mathrm{dmol}^{-1}$. It can be used to determine the $\alpha$-helicity of the protein by using the following simple calculation (Chen et al., 1972): \% $\alpha-$ helicity $=\left(\theta_{222}-\theta_{\min } / \theta_{\max }-\theta_{\min }\right) \times 100$, where $\theta_{222 \mathrm{~nm}}$ is the molar ellipticity of the observed protein, $\theta_{\min }=2340$ is the minimum value of the molar ellipticity at $222 \mathrm{~nm}$ that was calculated for the "unordered" fraction of five proteins, and $\theta_{\max }=30,300$ is the maximum value for the ellipticity at 222 $\mathrm{nm}$, as measured for the helical fraction of the five proteins. The estimated $\alpha$-helicity of ervatamin B is approximately $22 \%$ at neutral $\mathrm{pH}$.
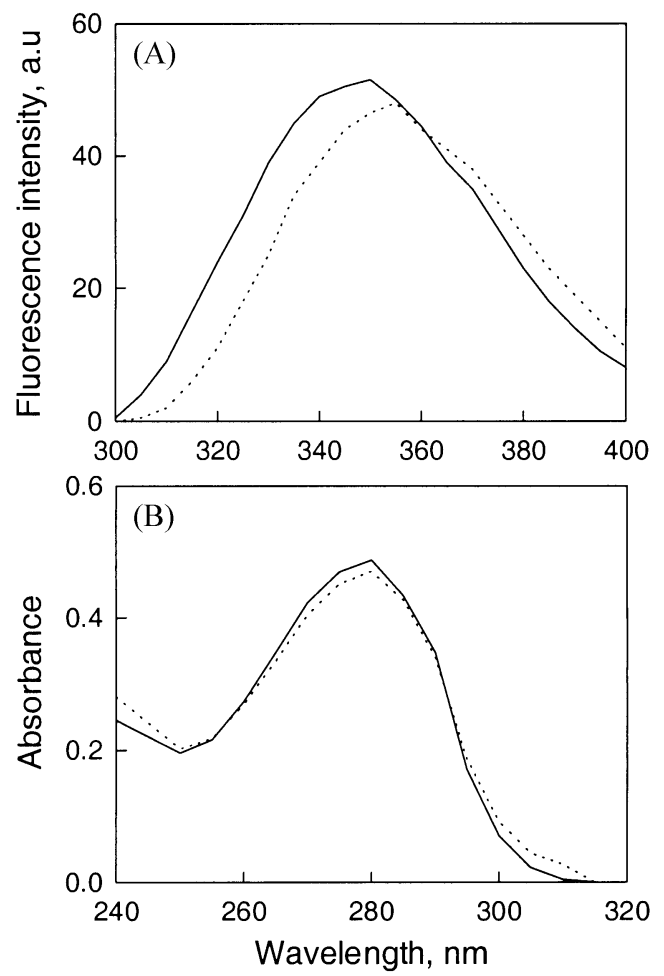

Fig. 2. Fluorescence and absorbance spectra of ervatamin B. (A) Intrinsic fluorescence spectra of ervatamin $\mathrm{B}$ at $(-) \mathrm{pH} 7.0$ and in (---) $6 \mathrm{M} \mathrm{GuHCl}$. Protein concentration was $0.025 \mathrm{mg} / \mathrm{ml}$. The excitation wavelength was $292 \mathrm{~nm}$ with slit widths of $10 \mathrm{~nm}$ and $5 \mathrm{~nm}$ for excitation and emission, respectively. (B) Absorbance spectra of ervatamin B at (-) pH 7.0 and in (---) $6 \mathrm{M} \mathrm{GuHCl}$. The samples were incubated for $24 \mathrm{~h}$ at $25^{\circ} \mathrm{C}$ before the measurements. Protein concentration was $0.16 \mathrm{mg} / \mathrm{ml}$.
In $6 \mathrm{M} \mathrm{GuHCl}$ ervatamin $\mathrm{B}$ loses all of its tertiary and secondary structural features. There is a complete disappearance of all of the prominent peaks in the peptide bond and aromatic regions (Fig. 1). Also, the protein is in the unfolded state (D-state).

Fluorescence spectra Fluorescence spectroscopy can provide information about the polarity of the tryptophan environment, as well as the solvent accessibility of the chromophores that are sensitive to local conformational changes at the tertiary level of folding (Schmid, 1989). Intrinsic fluorescence spectra of ervatamin $\mathrm{B}$ in native and completely unfolded states are shown in Fig. 2A. When excited at $292 \mathrm{~nm}$, ervatamin B showed an emission maximum at $350 \mathrm{~nm}$ in the native state. Spectra of the unfolded enzyme in $6 \mathrm{M} \mathrm{GuHCl}$ remains similar in shape, but the emission maximum shifts from $350 \mathrm{~nm}$ to $355 \mathrm{~nm}$ with a decrease in the intensity by about $8 \%$. This indicates that the tryptophan residues of ervatamin B are in a more polar environment than the native state, which is characteristic of unfolding.

Absorbance spectra The absorbance spectrum of the native enzyme is shown in Fig. 2B. Absorbance spectra of ervatamin $\mathrm{B}$ in the native and unfolded conditions show no significant differences in shape or absorbance maximum, which is at 279 nm.

Acid induced conformational changes in ervatamin B Changes in the tertiary structure of ervatamin $\mathrm{B}$ as a function of $\mathrm{pH}$ are shown in Fig. 3A. The change in ellipticity at 278 $\mathrm{nm}$ against $\mathrm{pH}$ follows a bell-shaped curve with loss of tertiary structure only beyond $\mathrm{pH} 3.0$ and 11.0. The overall near-UV CD spectral characteristics remain the same between $\mathrm{pH} 3.0$ and 11.0, and are typical of the native state with a positive peak at $278 \mathrm{~nm}$ and a negative band at $295 \mathrm{~nm}$. However, the negative peak was more intense above $\mathrm{pH} 9.0$; the positive peak was slightly less intense at $\mathrm{pH} 3.0$. At $\mathrm{pH} 2.0$ and below, all of the prominent peaks were absent, and the spectrum was identical to that in $6 \mathrm{M} \mathrm{GuHCl}$ (inset of Fig. $3 \mathrm{~A})$. This indicates that the enzyme lost its tertiary structure and is completely unfolded. The changes in the proteolytic activity with $\mathrm{pH}$ also follow a shape that is similar to the ellipticity at $278 \mathrm{~nm}$ (Fig. 3B). The enzyme is also fully active over the $\mathrm{pH}$ range 3.0-11.0 and drops only on either side of this range.

The effect of varying $\mathrm{pH}$, in presence and absence of salt, on the secondary structure of ervatamin B is shown in Fig. 3C. The enzyme retained most of its secondary structure up to $\mathrm{pH}$ 3.0, and a gradual decrease in ellipticity values below this $\mathrm{pH}$ was observed. Acid induced the unfolding of the enzyme, in the absence of any salt, followed by ellipticity at $220 \mathrm{~nm}$ that is non-cooperative with two transitions (Fig. 3C, open circles), which indicates the presence of intermediates in the process. The first transition, from the native state to the acid unfolded 


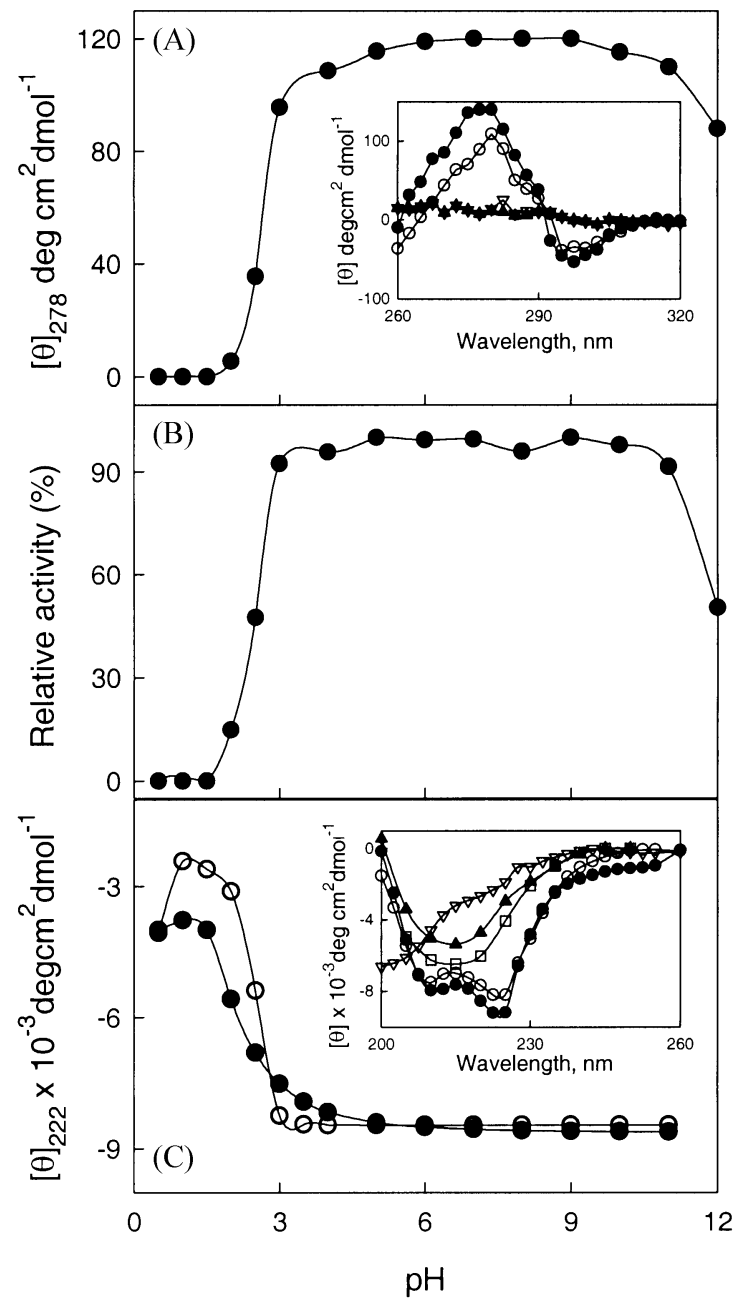

Fig. 3. $\mathrm{pH}$ dependent conformational changes of ervatamin B. (A) Ellipticity at $278 \mathrm{~nm}$. Inset. Near-UV CD spectra at ( $) \mathrm{pH} 7.0$, $(\bigcirc) \mathrm{pH} 3.0,(\nabla) \mathrm{pH} 2.0$ and $(\boldsymbol{\nabla}) \mathrm{pH}$ 0.5. Protein concentration was $0.7 \mathrm{mg} / \mathrm{ml}$. (B) Proteolytic activity measurements at $\mathrm{pH} 7.0$ were performed as described in Methods. (C) Ellipticity at $222 \mathrm{~nm}$ in the presence $(\lambda)$ and absence $(\bigcirc)$ of $0.5 \mathrm{M} \mathrm{KCl}$. Inset. Far-UV CD spectra at pH $7.0(\bigcirc)$, pH $3.0(\bigcirc), \mathrm{pH} 2.0(\nabla), \mathrm{pH} 0.5(\boldsymbol{\Delta})$, and $0.5 \mathrm{M} \mathrm{KCl}, \mathrm{pH} 2.0(\square)$. Protein concentration was $0.1 \mathrm{mg} / \mathrm{ml}$. The samples were incubated for $24 \mathrm{~h}$ at $25^{\circ} \mathrm{C}$ before the measurements.

state, occurs in the vicinity of $\mathrm{pH}$ 4.0-1.0. A similar transition is also observed in the aromatic CD region (Fig. 3A), between $\mathrm{pH} 4.0$ and 1.0. It reflects the loss of the native-like tertiary structure, which is not regained at lower $\mathrm{pH}$ values. The spectra are similar to that of the unfolded protein in $6 \mathrm{M}$ $\mathrm{GuHCl}$. Such a loss of secondary, as well as tertiary structure, yields the acid-unfolded state (Fink et al., 1994). This indicates incomplete unfolding that is evidenced by the residual molar ellipticity in the far-UV region compared to that in $6 \mathrm{M} \mathrm{GuHCl}$. Further addition of acid leads to a second transition between $\mathrm{pH} 1.5$ and 0.5 that is manifested as an increase in secondary structure (refolding), leading to the Astate. However, the presence of $0.5 \mathrm{M} \mathrm{KCl}$ induced a

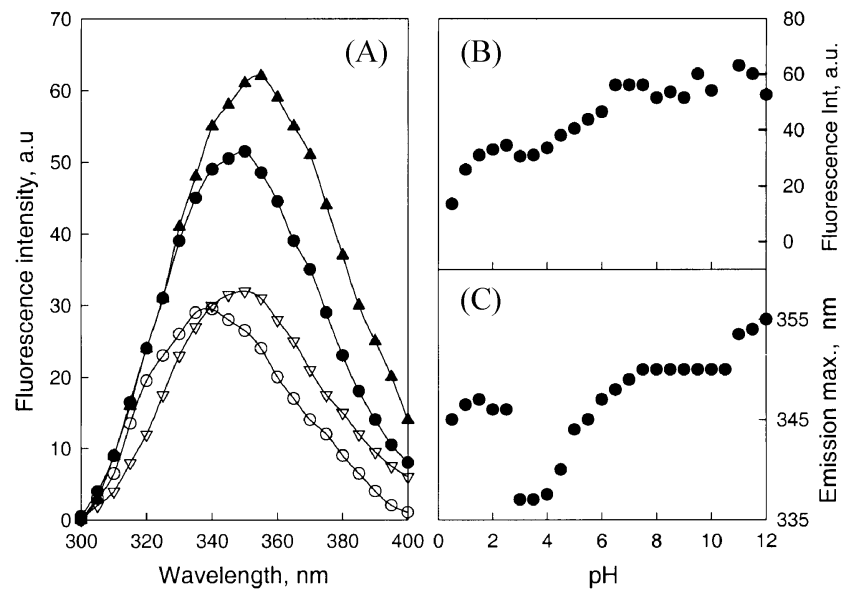

Fig. 4. Effect of $\mathrm{pH}$ on the intrinsic fluorescence of ervatamin B. (A) Intrinsic fluorescence spectra at $(\bigcirc) \mathrm{pH} 7.0,(\bigcirc) \mathrm{pH} 3.0,(\nabla)$ $\mathrm{pH} 2.0$, and $(\boldsymbol{\Delta}) \mathrm{pH}$ 11.0. The changes in the (B) fluorescence intensity and (C) wavelength maxima of Trp emission. Protein concentration was $0.025 \mathrm{mg} / \mathrm{ml}$. The excitation wavelength was at $292 \mathrm{~nm}$ with slit widths of $10 \mathrm{~nm}$ and $5 \mathrm{~nm}$ for excitation and emission, respectively.

cooperative transition (Fig. 3C, filled circle) between $\mathrm{pH}$ 4.00.5 , with no detectable intermediates as the enzyme passes from the native state directly to the A-state, regaining a slightly higher amount of secondary structure than at $\mathrm{pH} 0.5$. However, aggregation or salting out was observed at higher concentrations of added salt $(>0.5 \mathrm{M} \mathrm{KCl})$ at $\mathrm{pH} 1.0-2.5$. The far-UV CD spectra of ervatamin $\mathrm{B}$ at various $\mathrm{pH}$ are shown in the inset of Fig. 3C. Up to $\mathrm{pH}$ 3.0, all of the spectral features remain unchanged relative to the native state while both the negative peaks at 220-222 $\mathrm{nm}$ and $208 \mathrm{~nm}$ are lost between pH 2.5-1.0 with a marked decrease in ellipticity. However, the spectrum at $\mathrm{pH} 0.5$ shows a substantial secondary structure with a negative peak at $215 \mathrm{~nm}$ and a positive peak at $195 \mathrm{~nm}$, which is characteristic of predominant $\beta$-sheet, thus differing from either the native state or the acid unfolded state. The spectra between $\mathrm{pH}$ 2.5-1.0 in the presence of $\mathrm{KCl}$ are also similar in shape but with higher ellipticity. Hence, the addition of acid beyond $\mathrm{pH} 1.0$ leads to the formation of the A-state that is characterized by the presence of significant non-native secondary structure, and the absence of tertiary structure. In the A-state $(\mathrm{pH} 0.5)$, the mean residue ellipticity at $215 \mathrm{~nm}$ and $222 \mathrm{~nm}$ were $-5.4 \pm 0.25 \times 10^{3}$ deg. $\mathrm{cm}^{2} \mathrm{dmol}^{-1}$ and -4.1 $\pm 0.25 \times 10^{3}$ deg. $\mathrm{cm}^{2} \mathrm{dmol}^{-1}$, respectively. The ellipticity at 222 $\mathrm{nm}$ in the presence of $0.5 \mathrm{M} \mathrm{KCl}$ at $\mathrm{pH} 2.0$ is $-6.4 \pm 0.5 \times 10^{3}$ deg. $\mathrm{cm}^{2} \mathrm{dmol}^{-1}$. The change in overall ellipticity below $\mathrm{pH} 3.0$ may be due to the partial unfolding of the molecule, especially the alpha helix-rich regions.

An important point is that if the protein is incubated at a given $\mathrm{pH}$ and the activity is measured at the same $\mathrm{pH}$, then the activity is less than the value obtained when assayed under neutral conditions. However, the same sample gives an equivalent activity if assayed at neutral conditions. This 
observation, combined with the fact that the secondary and tertiary structural content is intact even at low $\mathrm{pH}$, shows that the enzyme is stable. It does not loose its proteolytic activity, even after a prolonged exposure to the $\mathrm{pH}$ range 3.0-11.0, and it is reversible to neutral $\mathrm{pH}$.

The $\mathrm{pH}$ dependence of intrinsic fluorescence properties of ervatamin B is shown in Fig. 4. Between pH 3.0 and 11.0, where protein is stable, the emission maximum (Fig. 4C) increases from $337 \mathrm{~nm}$ at low $\mathrm{pH}$ to $353 \mathrm{~nm}$ at high $\mathrm{pH}$ with the transition midpoint at about 5.8. The fluorescence intensity (Fig. 4B) increases by a factor of two over the same $\mathrm{pH}$ region with a similar transition midpoint.

Typical fluorescence spectra of ervatamin $\mathrm{B}$ at different $\mathrm{pH}$ are shown in Fig. 4A. At neutral $\mathrm{pH}$ the wavelength emission maximum was $350 \mathrm{~nm}$, and shifted to $338 \mathrm{~nm}$ by $\mathrm{pH} 3.0$ and 4.0 , while the fluorescence intensity was reduced to $53-57 \%$ of the native protein. However, there is a discontinuity in the changes of emission maximum when the protein unfolds, both in the acid region between $\mathrm{pH} 2.5$ and 3.0, and in the alkaline region between $\mathrm{pH} 10.5$ and 11.0. Both acid and alkaline unfolding causes an increase in emission maximum. Acid unfolding is accompanied by a further decrease in fluorescence intensity while alkaline transition is not (Fig. 4B). However, at $\mathrm{pH} 2.0$ and below the emission maximum shifts again to a higher wavelength $(345 \mathrm{~nm})$. At and above $\mathrm{pH} 11.0$, the emission maximum was at $355 \mathrm{~nm}$, indicating a complete unfolding of the molecule. There, as the shift in the emission maximum upon acidification is less in magnitude, it indicates a partial unfolding. The changes in the tryptophan environment in the protein molecule on acidification have been followed by changes in the fluorescence intensity and shift in emission maximum (Fig. 4B and 4C). The $\mathrm{pH}$ induced transition curve, obtained by following fluorescence intensity, is non-cooperative. It shows biphasic nature with one transition between $\mathrm{pH} 0.5$ to 3.5 with a midpoint of $\mathrm{pH} 1.01$, and the other between $\mathrm{pH} 3.0-11.0$ with a midpoint of $\mathrm{pH}$ approximately 5.85 . The $\mathrm{pH}$ transition curve that was obtained by following the shift in the fluorescence emission maximum is also biphasic with a similar trend as above, but there was a drastic fall in the wavelength maximum between $\mathrm{pH} 3.0$ and 4.0.

Between pH 7.0 and 3.0, the absorbance spectra are identical in shape and intensity. Below pH 3.0, however, there was only a very slight reduction in intensity without any changes in the overall shape of the spectra, hence they could not be used as an effective probe for these studies (data not shown).

GuHCl-induced unfolding The GuHCl-induced changes of ervatamin B were followed by CD (ellipticity at $278 \mathrm{~nm}$ and $220 \mathrm{~nm}$ ), fluorescence (wavelength emission maximum), and activity. Under neutral conditions, the chemical-induced transition curves were sigmoidal, as seen by the different measures (Fig. 5A). All of the structural changes take place between 2.35-4.0 M GuHCl with a transition mid-point at

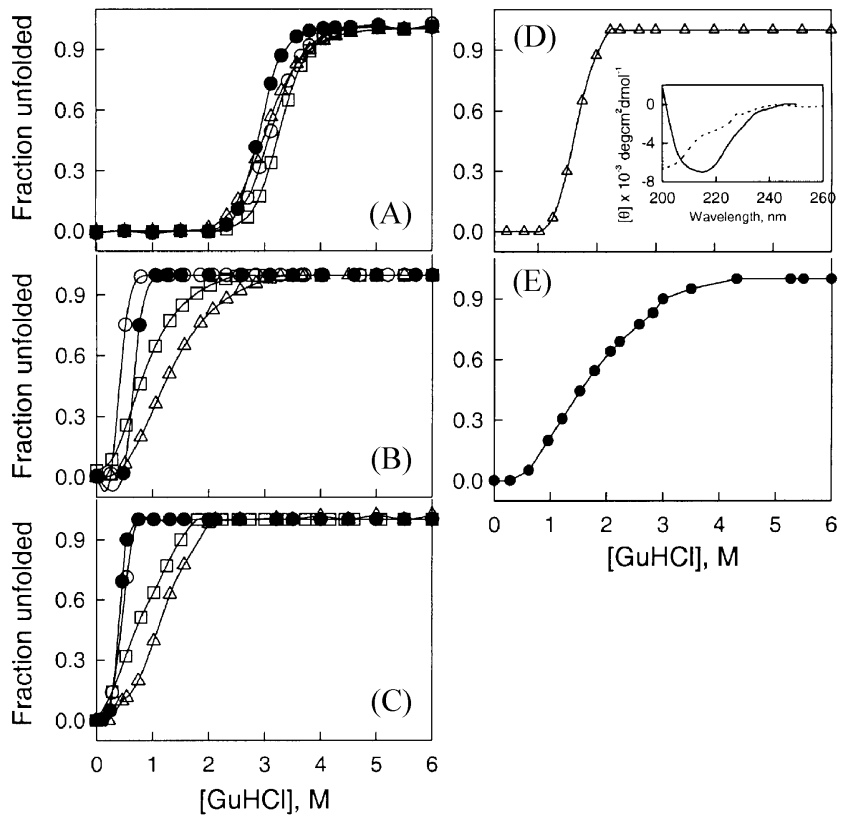

Fig. 5. Equilibrium $\mathrm{GuHCl}$ denaturation of ervatamin $\mathrm{B}$. The unfolding of ervatamin $\mathrm{B}$ was monitored at (A) $\mathrm{pH} 7.0$, (B) $\mathrm{pH}$ 4.0, (C) $\mathrm{pH} 3.0$, (D) $\mathrm{pH} 2.0$, and (E) $\mathrm{pH} 0.5$ by change in circular dichroism ellipticity at $278 \mathrm{~nm}$ ( ), in circular dichroism ellipticity at $222 \mathrm{~nm}(\triangle)$, in proteolytic activity $(\bigcirc)$, and in wavelength of maximum emission ( $\square$ ) arising from excitation at $292 \mathrm{~nm}$. The resulting data were normalized to fractions of unfolded protein and plotted. The samples were incubated in $\mathrm{GuHCl}$ for $24 \mathrm{~h}$ at $25^{\circ} \mathrm{C}$ before the measurements. Inset of (D): Far-UV spectra at $\mathrm{pH} 2.0$ in presence (-) and absence (---) of 0.25 $\mathrm{M} \mathrm{GuHCl}$.

$3.1 \pm 0.1 \mathrm{M} \mathrm{GuHCl}$. Upon unfolding of the molecule, no significant change in fluorescence intensity was seen, but the emission maximum suffered a shift of $5 \mathrm{~nm}$. The loss in proteolytic activity coincided with the loss in tertiary and secondary structures, which reflects a good correlation between the activity and structural integrity of the molecule. Thus, ervatamin B is structurally and functionally stable up to 2.35 M GuHCl.

Since ervatamin B was structurally stable with no irreversible loss of proteolytic activity, even after a prolonged exposure to a wide range of $\mathrm{pH}$ (3-11), it was important to check the structural integrity of the molecule at low $\mathrm{pH}$. Any subtle changes in the structure of the enzyme upon acidification should reflect its stability, and can be seen in its behavior towards denaturants.

The GuHCl-induced denaturation of ervatamin $\mathrm{B}$ at $\mathrm{pH} 4.0$ is shown in Fig. 5B. The unfolding transition curves, measured by different methods, are sigmoidal and noncoincidental with the activity, tertiary structure, intrinsic fluorescence, and secondary structure being lost in this order. The transition midpoints $\left(c_{m}\right)$ were $0.46 \pm 0.1,0.51 \pm 0.1,0.86$ \pm 0.1 , and $1.14 \pm 0.1 \mathrm{M} \mathrm{GuHCl}$, respectively. Denaturation of ervatamin B starts at a very low concentration of $\mathrm{GuHCl}$ at 


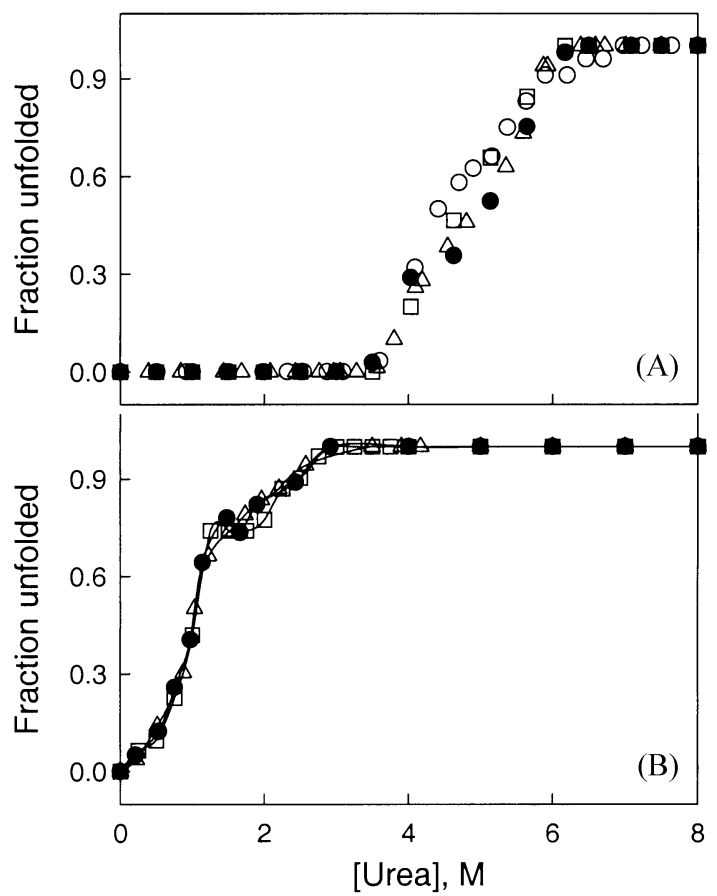

Fig. 6. Equilibrium urea denaturation of ervatamin B. (A) At $\mathrm{pH}$ 4.0. and (B) at $\mathrm{pH}$ 3.0. The unfolding of ervatamin $\mathrm{B}$ was monitored by a change in circular dichroism ellipticity at $278 \mathrm{~nm}$ (O), in circular dichroism ellipticity at $222 \mathrm{~nm}(\triangle)$, in proteolytic activity $(\bigcirc)$, and in wavelength of maximum emission $(\square)$ arising from excitation at $292 \mathrm{~nm}$. The resulting data were normalized to fractions of unfolded protein and plotted.

this $\mathrm{pH}$ (4.0). Loss in activity and tertiary structure took place between 0.25 and $1.0 \mathrm{M} \mathrm{GuHCl}$, whereas the secondary structural changes occurred between $0.25 \mathrm{M}$ and $2.5 \mathrm{M}$ $\mathrm{GuHCl}$. Changes in intrinsic fluorescence occurred between $0.25 \mathrm{M}$ and $3.0 \mathrm{M} \mathrm{GuHCl}$. Fluorescence intensity, however, showed no significant change (data not shown).

The overall characteristics of the GuHCl-induced unfolding of ervatamin $\mathrm{B}$ at $\mathrm{pH} 3.0$ were similar to that observed at $\mathrm{pH}$ 4.0 (Fig. 5C). Also, the activity and other structural parameters were lost in the same order, but with lower midpoints of $0.42 \pm 0.1,0.46 \pm 0.1,0.79 \pm 0.1$, and $1.16 \pm 0.1 \mathrm{M}$ $\mathrm{GuHCl}$ for proteolytic activity, tertiary structure, intrinsic fluorescence, and secondary structure, respectively.

When $\mathrm{pH}$ is further lowered below 3.0, the protein looses all the tertiary structure with a complete loss of proteolytic activity. The $\mathrm{GuHCl}$ unfolding of ervatamin $\mathrm{B}$ at $\mathrm{pH} 2.0$ was followed by far-UV CD (Fig. 5D). The loss in secondary structure followed a single transition with a transition midpoint at $1.64 \pm 0.1 \mathrm{M} \mathrm{GuHCl}$. Thus, $\mathrm{GuHCl}$ completely unfolds the partially denatured acid unfolded state of ervatamin B. It is to be noted that at a low concentration of $\mathrm{GuHCl}(0.25 \mathrm{M})$, far-UV CD spectra is predominantly $\beta$ sheeted, similar to the spectra of the protein in the A-state that is seen in acid-induced unfolding (inset of Fig. 5D). The ellipticity at $215 \mathrm{~nm}$ in this state is $-7.04 \pm 0.5 \times 10^{3}$ deg. $\mathrm{cm}^{2}$
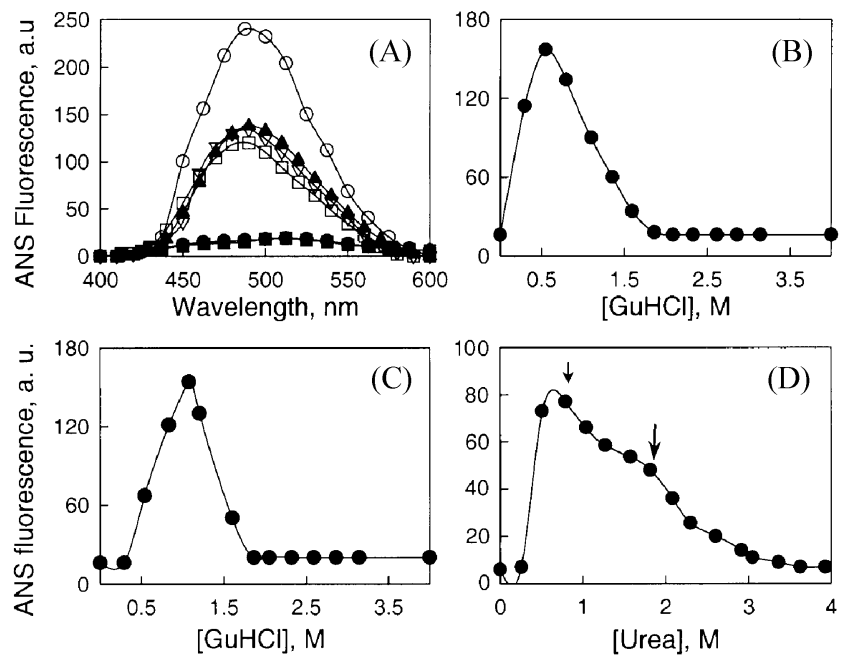

Fig. 7. Binding of ANS to ervatamin $B$ under various conditions. (A) ANS binding to ervatamin $\mathrm{B}$ in $(\mathbf{O}) \mathrm{pH} 7.0,(\boldsymbol{\square}) 6 \mathrm{M}$

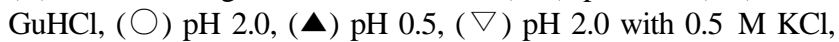
and ( $\square$ ) $0.25 \mathrm{M} \mathrm{GuHCl}, \mathrm{pH}$ 2.0. Protein concentration was $0.015 \mathrm{mg} / \mathrm{ml}$. ANS binding during $\mathrm{GuHCl}$-induced unfolding (B) at $\mathrm{pH} 3.0$ and $(\mathrm{C})$ at $\mathrm{pH}$ 4.0. The ANS fluorescence intensity at $480 \mathrm{~nm}$ was followed at protein concentrations of 0.015 and $0.025 \mathrm{mg} / \mathrm{ml}$, respectively. (D) ANS binding to ervatamin B during urea denaturation at $\mathrm{pH}$ 3.0. Two ANS binding concentrations are indicated by arrow. Protein concentration was $0.015 \mathrm{mg} / \mathrm{ml}$. In all of the cases, the protein was incubated in darkness with a 100-fold molar excess of ANS for more than $30 \mathrm{~min}$ at room temperature, and ANS fluorescence was measured with an excitation at $380 \mathrm{~nm}$.

$\mathrm{dmol}^{-1} . \mathrm{GuHCl}$ stabilizes this state and it shows a transition mid-point that is higher than those at $\mathrm{pH} 3.0$ and 4.0.

Similarly, the $\mathrm{GuHCl}$ induced unfolding of ervatamin $\mathrm{B}$ at a very low $\mathrm{pH}(0.5)$ was also a single transition (Fig. 5E). The transition mid-point is $1.61 \pm 0.1 \mathrm{M} \mathrm{GuHCl}$, as in the case of a similar measurement at $\mathrm{pH} 2.0$.

Urea induced unfolding Under neutral conditions, urea induced no structural perturbations to the protein molecule, and ervatamin B exhibits all of the proteolytic activity. However, urea-unfolding studies at as low a pH as 4.0 and 3.0 yielded some interesting results. At $\mathrm{pH} 4.0$, the urea induced changes that resulted (by various measures) in a single sigmoidal transition curve (Fig. 6A) with all the changes that occur between 3.5-6.5 M urea. The transition midpoints $\left(\mathrm{c}_{\mathrm{m}}\right)$ of the denaturation followed by different measures (activity, near-UV CD, far-UV CD and wavelength maximum), are approximately at $4.75 \pm 0.15 \mathrm{M}$. Emission maximum of intrinsic fluorescence shifted by $5 \mathrm{~nm}$ upon urea unfolding, and the fluorescence intensity changed little (data not shown). The loss in proteolytic activity upon unfolding, within the range of error, coincides with the loss in tertiary and secondary structures. This reflects a good correlation between the activity and structural integrity of the molecule. Thus, 
ervatamin B is structurally and functionally stable up to $3.5 \mathrm{M}$ urea concentration at $\mathrm{pH} 4.0$.

At $\mathrm{pH}$ 3.0, urea-induced unfolding of ervatamin B takes place at very low concentrations of the denaturant, and the unfolding characteristics are different from those observed at $\mathrm{pH}$ 4.0. All of the structural and functional changes occur between 0.25 and $3 \mathrm{M}$ urea, and the transition curves are coincidental. Further, the individual transitions that were observed by various measures are biphasic in nature (Fig. 6B). Initially, the structure and function of ervatamin B disappeared rapidly up to $1.5 \mathrm{M}$ urea with no further significant changes up to $1.75 \mathrm{M}$ urea, and followed by a slow decrease beyond this concentration. The $c_{m}$ in the region of rapid fall is at $0.937 \pm 0.1 \mathrm{M}$ urea, while the latter is at $2.16 \pm 0.1 \mathrm{M}$ urea. However, at $\mathrm{pH}$ 2.0, low concentrations of urea induced no structure in the enzyme, as in the case of $\mathrm{GuHCl}$.

ANS binding ANS preferentially binds to the enzyme in the A-state $(\mathrm{pH} 0.5$ or $\mathrm{pH} 0.5-2.5$ in presence of $0.5 \mathrm{M} \mathrm{KCl}$ or in $0.25 \mathrm{M} \mathrm{GuHCl}$ at $\mathrm{pH} 2.0$ ), compared to the native and completely unfolded states (Fig. 7A). ANS fluorescence intensity increases approximately five-fold, and the emission maximum shifts to a shorter wavelength $(490 \mathrm{~nm})$, when compared to the native or denatured states $(515 \mathrm{~nm})$. However, the extent of ANS binding to ervatamin $\mathrm{B}$ at $\mathrm{pH} 2.0$, in the presence of salt $(0.5 \mathrm{M} \mathrm{KCl})$, or a low denaturant $(0.25 \mathrm{M} \mathrm{GuHCl})$, is less than the binding that is seen in the absence of salt or a denaturant.

The extent of ANS binding to ervatamin B was also followed throughout the $\mathrm{GuHCl}$ and urea denaturation. Strong ANS binding to the protein was observed at low concentrations of $\mathrm{GuHCl}$, both at $\mathrm{pH} 3.0$ (Fig. 7B) and 4.0 (Fig. 7C). ANS fluorescence intensity increased approximately eight-fold, and the emission maximum shifted to a shorter wavelength $(480 \mathrm{~nm})$ compared to the native state $(515 \mathrm{~nm})$. The ANS binding was at the maximum during
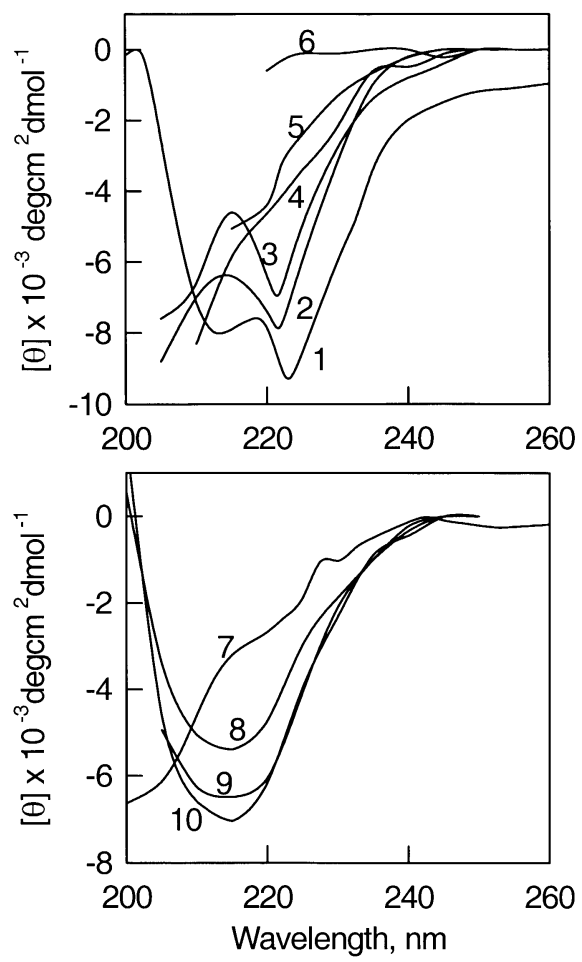

Fig. 8. Far-UV CD spectra of ervatamin $B$ under various conditions. The $\mathrm{CD}$ spectra at $\mathrm{pH} 7.0$ (1) and in $6 \mathrm{M} \mathrm{GuHCl}$ (6) are shown for comparison. Protein concentration was $0.1 \mathrm{mg} /$ $\mathrm{ml}$. The samples were incubated at the specified conditions for $24 \mathrm{~h}$ at $25^{\circ} \mathrm{C}$ before the measurement. The numbers indicate the far-UV CD spectra of ervatamin B under various conditions (Table 1).

$\mathrm{GuHCl}$ unfolding at $0.5 \pm 0.1 \mathrm{M} \mathrm{GuHCl}$ and $1.1 \pm 0.1 \mathrm{GuHCl}$ at $\mathrm{pH} 3.0$ and 4.0, respectively.

Similarly, the results on the ANS binding to ervatamin B during urea denaturation at $\mathrm{pH} 3.0$ are shown in Fig. 7D. The maximum amount of ANS binding is seen at $0.8 \pm 0.1 \mathrm{M}$ urea

Table 1. Structural properties of ervatamin B at different experimental conditions. Ervatamin B is in the native state in $50 \mathrm{mM}$ phosphate buffer, $\mathrm{pH} 7.0$, and the corresponding molar ellipticities in the near and far-UV CD region are considered as $100 \%$. The enzyme was equilibrated under various other conditions, as mentioned in the table below. Their corresponding molar ellipticities were calculated as \% structural content for comparison. This represents multiple intermediate states of the enzyme with different structural properties.

\begin{tabular}{|c|c|c|c|c|}
\hline Conformational state & Species & Conditions & $\%$ ellipticity at $278 \mathrm{~nm}$ & $\%$ ellipticity at $222 \mathrm{~nm}$ \\
\hline Native & 1 & $\mathrm{pH} 7.0$ & 100 & 100 \\
\hline Intermediate & 2 & $\mathrm{pH} 3.0,0.5 \mathrm{M} \mathrm{GuHCl}$ & 7 & 86 \\
\hline Intermediate* & 3 & $\mathrm{pH} 3.0,0.8 \mathrm{M}$ Urea & 69 & 70 \\
\hline Intermediate* & 4 & $\mathrm{pH} 4.0,1.1 \mathrm{M} \mathrm{GuHCl}$ & 1 & 51 \\
\hline Intermediate* & 5 & $\mathrm{pH} 3.0,1.95$ M Urea & 31 & 36 \\
\hline Denatured & 6 & $6 \mathrm{M} \mathrm{GuHCl}$ & 0 & 2 \\
\hline Acid-unfolded & 7 & $\mathrm{pH} 2.0$, no salt & 5 & 28 \\
\hline Intermediate & 8 & $\mathrm{pH} 0.5$ & 0 & 59 \\
\hline Intermediate & 9 & $\mathrm{pH} 2.0,0.5 \mathrm{M} \mathrm{KCl}$ & 0 & 71 \\
\hline Intermediate & 10 & $\mathrm{pH} 2.0,0.25 \mathrm{M} \mathrm{GuHCl}$ & 0 & 77 \\
\hline
\end{tabular}

*Intermediates where dominant ANS binding is seen. 
concentrations with an increase of eight-fold in fluorescence intensity. Interestingly, another shoulder or inflection on the ANS binding curve with lower fluorescence intensity was observed at $1.9 \pm 0.1 \mathrm{M}$ urea.

However, such ANS binding was not observed in urea denaturation at $\mathrm{pH} 4.0$, or at higher $\mathrm{pH}$ in the presence of any denaturants. It is to be noted that at $\mathrm{pH} 3.0$, ANS binding was observed at a protein concentration of $0.015 \mathrm{mg} / \mathrm{ml}$, while at $\mathrm{pH} 4.0$ a higher concentration of the protein $(0.05 \mathrm{mg} / \mathrm{ml})$ was necessary.

CD spectra of the states with maximum ANS binding In view of the maximum ANS binding that is observed at intermediate concentrations of $\mathrm{GuHCl}$ and urea during unfolding, the far-UV CD spectra of ervatamin $\mathrm{B}$ at the specific concentrations of the denaturant are shown in Fig. 8. At $0.5 \mathrm{M} \mathrm{GuHCl}, \mathrm{pH} 3.0$, the far-UV CD spectrum indicates a high $\alpha$-helical content, which is close to the helical content of the native enzyme at $\mathrm{pH} 3.0$ (Table 1). However, at $1.1 \mathrm{M}$ $\mathrm{GuHCl}, \mathrm{pH} 4.0$, the helical content was much less (Table 1). In $0.8 \mathrm{M}$ urea, $\mathrm{pH} 3.0$, the enzyme showed a helicity of $15 \%$, and the far-UV CD spectrum was predominantly $\alpha$-helical with the retention of substantial tertiary structure. However, at $1.95 \mathrm{M}$ urea the structural contents were very low (Table 1). Under all of these conditions, the tertiary structure is either drastically reduced or absent with complete loss of proteolytic activity. The far-UV CD spectra of native and denatured ervatamin $\mathrm{B}$ are also included in the figure for reference. The far-UV CD spectra of ervatamin $B$ in the intermediate conformations in the acid unfolding pathway, where significant ANS binding was observed, are also shown.

\section{Discussion}

The physicochemical characteristics of ervatamin B have been elucidated to get an insight into the structure-function relationship of the enzyme in view of its stability towards $\mathrm{pH}$ and denaturants. Circular dichroism, absorbance, and intrinsic fluorescence (along with activity measurements) were used to study the solution conformation of ervatamin B, as well as its unfolding by various denaturants. Ervatamin B belongs to the $\alpha+\beta$ class of proteins, as seen by $\mathrm{CD}$, and members of this class present separate $\alpha$-helix and $\beta$-sheet rich regions (Levitt and Chothia, 1976). This is actually the case in papain, whose molecule has an all- $\alpha$ domain and an antiparallel $\beta$-sheet domain (Kamphuis et al., 1984). Though only preliminary Xray data for ervatamin $\mathrm{B}$ crystals have been obtained in our laboratory (Chakrabarti et al., 1999), and the structure solution is in progress, it may be safely concluded from the $\mathrm{CD}$ data that ervatamin $\mathrm{B}$ also belongs to the $\alpha+\beta$ class. The overall CD spectrum of ervatamin B is comparable to papain, chymopapain (Solis-Mendiola et al., 1992), and ervatamin C (Kundu et al., 1999), but it differed from them in some finer details. For example, the negative peak at $295 \mathrm{~nm}$ in the nearUV CD spectra of ervatamin B is more intense than in papain.
Also, in ervatamin B the negative signal at $222 \mathrm{~nm}$ is more intense than the signal at $208 \mathrm{~nm}$, which is unlike ervatamin $\mathrm{C}$, where the reverse is true. Thus, like papain, ervatamin B retained all of the native features in the $\mathrm{pH}$ range 3-11, indicating high rigidity of the molecule, but it is less stable than ervatamin C (Kundu et al., 1999).

Acid induced unfolding Acid induced changes of ervatamin $\mathrm{B}$ as a function of $\mathrm{pH}$ indicate that the protein is structurally and functionally stable over a $\mathrm{pH}$ range of 3.0 to 11.0, and loses integrity on either side of this $\mathrm{pH}$ range. The acid-induced unfolding transition of ervatamin $\mathrm{B}$ in the absence of added salt, was incomplete and appears to involve a conversion from the native state to a somewhat collapsed unfolded state with no tertiary structure and some residual secondary structure along with strong ANS binding (Fig. 3C and 7A). Such a acid-induced state appears to be similar to the acid unfolded states that were observed in cytochrome $\mathrm{c}$ and apomyoglobin (Ohgushi and Wada, 1983; Goto and Fink, 1989). At very low $\mathrm{pH}$, the induction of an additional secondary structure was observed, driving the protein into the A-state. In presence of a low-salt concentration, however, the enzyme switches from the native state to the A-state directly. This behavior is typical of the type IC proteins like papain, parvalbumin, and ribonuclease A (Fink et al., 1994). However, compared to other proteins of the type IC, the A-state is observed at very low $\mathrm{pH}$ for ervatamin $\mathrm{B}$. Another interesting feature of ervatamin $\mathrm{B}$ in the A-state is the change in the nature of the far-UV CD spectrum, which is predominantly of $\beta$-sheet, unlike the native state.

Similarly, the dependence of intrinsic fluorescence properties (emission maximum and intensity) of ervatamin $\mathrm{B}$ as function of $\mathrm{pH}$ also reveals that the enzyme is stable in the $\mathrm{pH}$ range of 3.0 to 11.0. Thus, the focus needs to be on the status of the enzyme at very low $\mathrm{pH}$. Any subtle changes in the molecular structure of the enzyme, especially at low $\mathrm{pH}$, should reflect in its stability towards chemical denaturants and temperature, etc. Therefore, urea and GuHCl-induced unfolding of ervatamin B at low $\mathrm{pH}$ is carried out. The equilibrium unfolding of ervatamin B by various denaturants also reveal the high stability of the enzyme. The enzyme retains all of its structure and activity over a wide range of $\mathrm{pH}$, and falls only beyond this range. It retains activity in the presence of urea, under neutral conditions, as does papain. However, like papain (Kimmel and Smith, 1957) and unlike ervatamin C (Sundd et al., 1998), it is completely susceptible to urea at low $\mathrm{pH}$. The denaturation characteristics of ervatamin B are different from papain (Hernandez-Arana and Soriano-Carcia, 1988; Xiao et al., 1993; Edwin and Jagannadham, 1998), or ervatamin C (Kundu et al., 1999). Ervatamin B also differs from other proteases in its intrinsic fluorescence and ANS binding properties. These observations, together with the difference in $\mathrm{CD}$ spectra, probably suggest a different folding pattern and structural integrity for ervatamin B. 
Urea-induced unfolding Under neutral conditions, urea induced no unfolding of ervatamin $\mathrm{B}$, and the protein was active. However, urea-unfolding studies at low $\mathrm{pH}$ (3.0 and 4.0) yielded some interesting results. At $\mathrm{pH} 4.0$, the ureainduced unfolding curves that were obtained by various measures were sigmoidal and coincidental (Fig. 6A) showing the absence of intermediates in the unfolding pathway. At $\mathrm{pH}$ 3.0, urea induced unfolding of ervatamin B takes place at lower concentrations while the unfolding characteristics are different. All the structural and functional changes occur between 0.25 and $3 \mathrm{M}$ urea and the transition curves are coincidental. Further, the individual transitions obtained by various method are biphasic in nature (Fig. 6B). However, at $\mathrm{pH} 2.0$, low concentration of urea did not induce any structure in the enzyme as in the case of $\mathrm{GuHCl}$.

The most interesting and unique characteristic of ervatamin $\mathrm{B}$ is the ANS binding that is observed not only at low $\mathrm{pH}$, but also during chemical induced denaturation. The maximum amount of ANS binding is seen at the $0.8 \pm 0.1 \mathrm{M}$ urea concentration, and another shoulder or inflection on the ANS binding curve with lower fluorescence intensity was observed at $1.9 \pm 0.1 \mathrm{M}$ urea (Fig. 7D). Moreover, the transition midpoints in urea denaturation (Fig. 6B) coincide with the respective denaturant concentration where ANS binding was dominant. Such intermediates, in the presence of denaturants and the concomitant ANS binding, are a unique property of ervatamin B among the plant cysteine proteases of the papain superfamily. They may have implications in the kinetic pathway of protein folding. However, such ANS binding was not observed in urea denaturation at $\mathrm{pH} 4.0$, or at higher $\mathrm{pH}$ in the presence of denaturants.

GuHCl-induced unfolding The GuHCl-induced changes of ervatamin B were followed by various probes (ellipticity at $278 \mathrm{~nm}$ and $220 \mathrm{~nm}$ ), fluorescence (wavelength emission maximum), and activity (Fig. 5). Under neutral conditions, the chemical-induced transition curves were sigmoidal, and all of the structural changes took place between 2.35-4.0 M GuHCl with similar transition mid-points. With the lowering of the $\mathrm{pH}$, the unfolding transition curves are sigmoidal, but become non-coincidental, reflecting the presence of intermediates in the unfolding pathway. Denaturation of ervatamin B starts at a very low concentration of $\mathrm{GuHCl}$ at $\mathrm{pH} 4.0$. The overall characteristics of $\mathrm{GuHCl}$-induced unfolding of ervatamin $\mathrm{B}$ at $\mathrm{pH} 3.0$ were similar to that observed at $\mathrm{pH} 4.0$, and the activity and other structural parameters were lost in a similar order, but with lower mid-points. Further lowering of $\mathrm{pH}$ below 3.0 disrupts all of the tertiary structure with a complete loss of proteolytic activity. The loss in secondary structure followed a single transition with a lower transition midpoint. Thus, GuHCl completely unfolds the partially denatured acidunfolded state of ervatamin B. Further, it is to be noted that at low concentrations of $\mathrm{GuHCl}(0.25 \mathrm{M})$ far-UV CD spectra is predominantly $\beta$-sheeted, with a shape similar to the A-state that is seen in acid-induced unfolding. This indicates that
$\mathrm{GuHCl}$ stabilizes this state, and shows a transition mid-point that is higher than those at $\mathrm{pH} 3.0$ and 4.0. Similarly, the $\mathrm{GuHCl}$-induced unfolding of ervatamin $\mathrm{B}$ at a very low $\mathrm{pH}$ (0.5) also followed a single transition.

The other interesting and unique characteristic of ervatamin $\mathrm{B}$ is the ANS binding that is observed not only at low $\mathrm{pH}$, but also during $\mathrm{GuHCl}$ denaturation. The maximum amount of ANS binding that is seen at intermediate concentrations of $\mathrm{GuHCl}$ during denaturation (both at $\mathrm{pH} 3.0$ and 4.0) coincides with the transition midpoints (Fig. 7B and 7C).

Conclusions The present investigation identified a number of forms of ervatamin B under various conditions (Table 1). The presence of such multiple equilibrium partially-folded intermediates that differed in the amount of secondary structure, globularity, stability, and compactness have been reported in other proteins (Uversky et al., 1998; Tcherkasskaya and Ptitsyn, 1999; Uversky et al., 1999). They may play an important role in the correct folding of the enzyme. It is being speculated that these partially-folded intermediates probably consist of ensembles of substrates with a common core of native-like secondary structure, which is responsible for their stability. Consequently, it is likely that the intermediates may represent the equilibrium counterparts of transient kinetic intermediates (Uversky et al., 1998).

All of the intermediates had a substantial secondary structure, as well as a strong binding to ANS. In addition, species 2, 4, 8, 9, and 10 have no proteolytic activity or tertiary structure. All of the characteristics of these forms of ervatamin B are typical of molten globule state (Ptitsyn, 1995), and the states seem to be molten globule-like as in some other proteins (Kuwajima et al., 1976; Nozaka et al., 1978; Kim and Baldwin 1982; Goto et al., 1990a, b; Zerovnik et al., 1999).

The equilibrium unfolding of ervatamin $\mathrm{B}$ at higher $\mathrm{pH}$ (>4.0) is cooperative, and the protein molecule unfolds as a single entity. The similarity in denaturation curves that were obtained by various measures indicates that the changes in the environment of the excitable tryptophan residues, as well as the changes in secondary and tertiary structure, occur concurrently. Such unfolding transitions can be fitted to twostate mechanism $(\mathrm{N} \rightarrow \mathrm{D})$ under equilibrium conditions, as in the case of small proteins (Privalov, 1979; Kim and Baldwin, 1982). However, the presence of a number of intermediate states in ervatamin B is inconsistent with the simple two-state folding behavior.

In $\mathrm{GuHCl}$ denaturation at $\mathrm{pH}$ 3.0, an intermediate is observed with a higher secondary structure, but very little tertiary structure along with the strong ANS binding. The $\mathrm{GuHCl}$ concentration, where the ANS binding was maximum, was approximately the same as the $c_{m}$ of the transition curve that was followed by wavelength maxima of intrinsic fluorescence. In $\mathrm{GuHCl}$ denaturation at $\mathrm{pH}$ 4.0, another intermediate was seen with a lesser secondary structure with no tertiary structure, which appears like the denatured state 
with considerable ANS binding. The $\mathrm{GuHCl}$ concentrations, where the ANS binding was maximum both at $\mathrm{pH} 3.0$ and 4.0 , coincided with the transition midpoint $\left(\mathrm{c}_{\mathrm{m}}\right)$ of the $\mathrm{GuHCl}-$ induced unfolding curve that was obtained by fluorescence emission maximum. On the other hand, two intermediate states are observed during urea induced unfolding ervatamin $\mathrm{B}$ at $\mathrm{pH}$ 3.0. One intermediate had a high secondary structural content along with a substantial tertiary structure at low urea concentration, while the other had a lower secondary and tertiary structural content at a higher concentration of urea. The binding of ANS was also maximum at two urea concentrations, which coincided roughly with the transition midpoints $\left(\mathrm{c}_{\mathrm{m}}\right)$ of urea-induced unfolding that was obtained by fluorescence emission maximum. Hence, the equilibriumunfolding pathway of ervatamin B involves two intermediates, one is native-like while the other resembles the denatured state. It can be generalized as,

$$
\stackrel{\text { GuHCL/Urea }}{\longrightarrow} \mathrm{I}_{1} \stackrel{\text { GuHCL/Urea }}{\longrightarrow} \mathrm{I}_{2} \stackrel{\text { GuHCL/Urea }}{\longrightarrow} \mathrm{D}
$$

However, it should be noted that $I_{1}$ and $I_{2}$ are not the same states in the urea and $\mathrm{GuHCl}$-induced unfolding pathway. $\mathrm{I}_{1}$ and $I_{2}$ in the urea-induced unfolding with substantial tertiary structure are similar to the intermediate that was reported by Marmorino et al. (1998). Therefore, it is likely that the first state with high structural content is probably an early intermediate, while the second one is a late intermediate in the protein unfolding. Similar observations have not been reported in papain or other proteases of the papain superfamily.

This conclusion probably implies that different structural parts of the molecule are stabilized differentially in presence of denaturants, and they unfold sequentially. The different structural parts may be different domains in the enzyme; therefore, they provide evidence for the presence of domains in ervatamin B. In the case of cardiac troponin I (Morjana and Tal, 1998), the urea denaturation curves are biphasic, which indicates the presence of a stable folding intermediate, which might be related to the two-domain architecture of troponin I. Similar observations have suggested the presence of domains in the hormone-sensitive lipase (Osterlund et al., 1999) structure also.

Acknowledgments The financial assistance from the University Grants Commission, Council of Scientific and Industrial Research, and the Department of Biotechnology, India is acknowledged. Authors thank Dr. P K Ambhast for his help in refining the manuscript.

\section{References}

Arai, M. and Kuwajima, K. (1996) Rapid formation of a molten globule intermediate in refolding of alpha-lactalbumin. Folding and Design 1, 275-287.

Balasubramanian, D. and Kumar, C. (1976) Recent studies of the circular dichroism and optical rotatory dispersion of biopolymers. Applied Spectroscopy Reviews 11, 223-286.

Bychkova, V. E., Dujsekina, A. E., Klenin, S. I., Tiktopulo, E. I., Uversky, V. N. and Ptitsyn, O. B. (1996) Molten globule-like state of cytochrome $\mathrm{c}$ under conditions simulating those near the membrane surface. Biochemistry 35, 6058-6063.

Chakrabarti, C., Biswas, S., Kundu, S., Sundd, M., Jagannadham, M. V. and Dattagupta, J. K. (1999) Crystallization and preliminary X-ray analysis of ervatamin $\mathrm{B}$ and $\mathrm{C}$, two thiol proteases from Ervatamia coronaria. Acta Crystallogr. D55, 1074-1075.

Chen, Y. H., Yang, J. T. and Martinez, H. M. (1972) Determination of the secondary structures of proteins by circular dichroism and optical rotatory dispersion. Biochemistry 11, 4120-4131.

Dobson, C. M. (1992) Unfolded proteins, compact states and molten globules. Curr. Opin. Struct. Biol. 2, 6-12.

Edwin, F. and Jagannadham, M. V. (1998) Sequential unfolding of papain in molten globule state. Biochem. Biophys. Res. Comm. 252, 654-660.

Fink, A. L., Calciano, L. J., Goto, Y., Kurotsu, T. and Palleros, D. R. (1994) Classification of acid denaturation of proteins: intermediates and unfolded states. Biochemistry 33, 1250412511.

Garel, J. R. (1992) Folding of large proteins: Multidomain and multisubunit proteins; in Protein Folding, Creighton, T. E. (ed.), pp. 405-454. Freeman, New York, New York.

Gast, K., Zirwer, D., Muller-Frohne, M. and Damaschun, G. (1998) Compactness of the kinetic molten globule of bovine alpha-lactalbumin: a dynamic light scattering study. Protein Sci. 7, 2004-2011.

Goto, Y. and Fink, A. L. (1989) Conformational states of $\beta$ lactamase: molten-globule states at acidic and alkaline $\mathrm{pH}$ with high salt. Biochemistry 28, 945-952.

Goto, Y., Calciano, L. J. and Fink, A. L. (1990a) Acid-induced folding of proteins. Proc. Natl. Acad. Sci. USA 87, 573-577.

Goto, Y., Takahashi, N. and Fink, A. L. (1990b) Mechanism of acid-induced folding of proteins. Biochemistry 29, 3480-3488.

Harding, M. M., Williams, D. H. and Woolfson, D. N. (1991) Characterization of a partially denatured state of a protein by two-dimensional NMR: reduction of the hydrophobic interactions in ubiquitin. Biochemistry 30, 3120-3128.

Hernandez-Arana, A. and Soriano-Garcia, M. (1988) Detection and characterization by circular dichroism of a stable intermediate state formed in the thermal unfolding of papain. Biochim. Biophys. Acta 954, 170-175.

Kamphuis, I. G., Kalk, K. H., Swarte, M. B. and Drenth, J. (1984) Structure of papain refined at $1.65 \AA$ resolution. J. Mol. Biol. 179, 233-256.

Khorasanizadeh, S., Peters, I. D., Butt, T. R. and Roder. H. (1993) Folding and stability of a tryptophan containing mutant of ubiquitin. Biochemistry 32, 7054-7063.

Khurana, R., and Udgaonkar, J. B. (1994) Equilibrium unfolding studies of barstar: evidence for an alternative conformation which resembles a molten globule. Biochemistry 33, 106-115.

Kim, P. S. and Baldwin R. L. (1982) Specific intermediates in the folding reactions of small proteins and the mechanism of protein folding. Annu. Rev. Biochem. 51, 459-489.

Kim, P. S. and Baldwin, R. L. (1990) Intermediates in the folding reactions of small proteins. Annu. Rev. Biochem. 59, 631-660.

Kimmel, J. R. and Smith, E. L. (1957) The properties of papain. 
Adv. Enzymol. 19, 267-334.

Kundu, S., Sundd, M. and Jagannadham, M. V. (1999) Structural characterization of a highly stable cysteine protease ervatamin C. Biochem. Biophys. Res. Commun. 264, 635-642.

Kundu, S., Sundd, M. and Jagannadham, M. V. (2000) Purification and characterization of a stable cysteine protease ervatamin $\mathrm{B}$, with two disulfide bridges, from the latex of Ervatamia coronaria. J. Agric. Food Chem. 48, 171-179.

Kuwajima, K., Nitta, K., Yoneyama, M. and Sugai, S. (1976) Three state denaturation of $\alpha$-lactalbumin by guanidine hydrochloride. J. Mol. Biol. 106, 359-373.

Kuwajima, K., Semisotnov, G. V., Finkelstein, A. V., Sugai, S. and Ptitsyn, O. B. (1993) Secondary structure of globular proteins at the early and the final stages in protein folding. FEBS Lett. 334, 265-268.

Levitt, M., and Chothia, C. (1976) Structural patterns in globular proteins. Nature 261, 552-558.

Manavalan, P. and Johnson, W. C. (1983) Sensitivity of circular dichroism to protein tertiary structure class. Nature 305, 831832.

Marmorino, J. L., Lehti, M. and Pielak, G. J. (1998) Native tertiary structure in an A-state. J. Mol. Biol 275, 379-388.

Morjana, N. and Tal., R. (1998) Expression and equilibrium denaturation of cardiac troponin I: stabilization of a folding intermediate during denaturation by urea. Biotechnol. Appl. Biochem. 28, 7-17.

Nozaka, M., Kuwajima, K., Nitta, K. and Sugai, S. (1978) Detection and characterization of the intermediate on the folding pathway of human $\alpha$-lactalbumin. Biochemistry 17, 3753-3758.

Ohgushi, M. and Wada, A. (1983) Molten-globule state: a compact form of globular proteins with mobile side chains. FEBS Lett. 164, 21-24.

Osterlund, T., Beussman, D. J., Julenius, K., Poon, P. H., Linse, S., Shabanowitz, J., Hunt, D. F., Schotz, M. C., Derewenda, Z. S. and Holm, C. (1999) Domain identification of hormonesensitive lipase by circular dichroism and fluorescence spectroscopy, limited proteolysis and mass spectrometry. $J$. Biol. Chem. 274, 15382-15388.

Privalov, P. L. (1979) Stability of proteins: small globular proteins. Adv. Protein Chem. 33, 167- 241.

Ptitsyn, O. B. (1992) The molten globule state; in Protein Folding, Creighton, T. E. (ed.), pp. 243-300. Freeman, New York, New York.

Ptitsyn, O. B. (1995) Molten globule and protein folding. $A d v$. Protein Chem. 47, 83-229.

Ptitsyn, O. B., Pain, R. H., Semisotnov, G. V., Zerovnik, E. and Razgulyaev, O. I. (1990) Evidence for a molten globule state as a general intermediate in protein folding. FEBS Lett. 262, 20-24.

Schmid, F. X. (1989) Spectral methods of characterizing protein conformation and conformational changes. In Protein Structure: A Practical Approach, (Creighton, T.E., ed.), pp. 251-285. IRL Press, Oxford, U.K.

Semisotnov, G. V., Rodionova, N. A., Razgulyaev, O. I., Uversky, V. N., Gripas, A. F. and Gilmanshin, R. I. (1991) Study of the molten globule intermediate state in protein folding by a hydrophobic fluorescent probe. Biopolymers 31, 119-128.

Shirley, B. A. (1995) Urea and guanidine hydrochloride denaturation curves. In Protein Folding and Stability, Shirley, B. A. (Eds) pp. 177-190, Humana Press, Totowa, New Jersey.

Solis-Mendiola, S., Arroyo-Reyna, A. and Hernandez-Arana, A. (1992) Circular dichroism of cysteine proteinases from papaya latex. Evidence of differences in the folding of their polypeptide chains. Biochim. Biophys. Acta 1118, 288-292.

Strickland, E. H. (1974) Aromatic contributions to circular dichroism spectra of proteins. CRC Crit. Rev. Biochem. 2, 113175.

Strickland, E. H., Hortwiz, J. and Billups, C. (1969) Fine structure in the near-ultraviolet circular dichroism and absorption spectra of tryptophan derivatives and chymotrypsinogen A at $77^{\circ} \mathrm{K}$. Biochemistry 8, 3205-3213.

Sundd, M., Kundu, S., Pal, G. P. and Medicherla, J. V. (1998) Purification and characterization of a highly stable cysteine protease from the latex of Ervatamia coronaria. Biosci. Biotech. Biochem. 62, 1947-1955.

Tcherkasskaya, O. and Ptitsyn, O. B. (1999) Molten globule versus variety of intermediates: influence of anions on $\mathrm{pH}-$ denatured apomyoglobin. FEBS Lett. 455, 325-331.

Uversky, V. N., Karnoup, A. S., Khurana, R., Segel, D. J., Doniach, S. and Fink, A. L. (1999) Association of partially folded intermediates of Staphylococcal nuclease induces structure and stability. Protein Sci. 8, 161-173.

Uversky, V. N., Karnoup, A. S., Segel, D. J., Seshadri, S., Doniach, S. and Fink, A. L. (1998) Anion-induced folding of Staphylococcal nuclease: characterization of multiple equilibrium partially folded intermediates. J. Mol. Biol. 278, 879-894.

Xiao, J., Liang, S. -J. and Tsou, C. -L. (1993) Inactivation before significant conformational change during denaturation of papain by guanidine hydrochloride. Biochim. Biophys. Acta 1164, 5460.

Zerovnik, E., Janjic, V., Francky, A. and Mozetic-Francky, B. (1999) Equilibrium and transient intermediates in folding of human macrophage migration inhibitory factor. Eur. $J$. Biochem. 260, 609-618. 